\title{
PRIORITIZING CHILDREN'S BEST INTERESTS IN CANADIAN YOUTH JUSTICE: ARTICLE 3 OF THE UN CONVENTION ON THE RIGHTS OF THE CHILD AND CHILD- FRIENDLY ALTERNATIVES
}

\author{
Étienne F. Lacombe*
}

The UN Convention on the Rights of the Child confers on children a number of rights, not the least of which is the guarantee that their best interests shall be a primary consideration in all actions that concern them. This article applies the Best Interests of the Child [BIC] principle - a widespread concept in family law - to the context of criminal policy. It calls for a rebalancing of Canadian youth justice so as to prioritize children's best interests. As marginalized societal actors, children are at risk of seeing their interests increasingly overlooked if they are not brought to the fore.

Once a defining feature of Canada's response to juvenile delinquency, the BIC principle has waned in the face of sweeping penal populism. Examples from Scotland, Scandinavia and Washington reveal means by which child-friendly justice systems can withstand the influence of punitive public sentiment. Mirroring such approaches in Canada would require repurposing the deeply engrained concept of proportionality and viewing children's interests as inherent to advancing public safety.

La Convention relative aux droits de l'enfant (convention des Nations Unies) confère aux enfants plusieurs droits, l'un des plus importants étant la garantie que l'intérêt supérieur de l'enfant doit être une considération primordiale dans toutes les décisions qui le concernent. Dans cet essai, l'auteur applique le principe de l'intérêt supérieur de l'enfant - concept largement répandu en droit de la famille - au contexte des politiques en matière criminelle. Il évoque la nécessité de rééquilibrer le système canadien de justice pour les jeunes afin de prioriser l'intérêt supérieur des enfants. En raison du rôle marginal qu'ils jouent dans la société, les enfants sont de plus en plus exposés au risque que leurs intérêts soient ignorés s'ils ne sont pas mis de l'avant.

Dans la foulée de la progression du populisme pénal, le principe de l'intérêt supérieur de l'enfant, qui constituait jadis un élément fondateur de l'intervention du Canada en matière de délinquance juvénile, a peu à peu été ébranlé. À l'aide d'exemples de situations vécues en Écosse, en Scandinavie et au Washington, l'auteur explique qu'un système de justice adapté aux enfants peut se prémunir contre l'influence des sentiments du public quant à une démarche punitive. Cependant, pour utiliser des approches semblables au Canada, il serait nécessaire de redéfinir le concept profondément enraciné de la proportionnalité en reconnaissant que les intérêts des enfants sont intrinsèquement liés à la sécurité publique.

* $\quad$ B.C.L./LL.B. Candidate (Dec. 2017), Faculty of Law, McGill University. 


\section{PREFACE}

The inspiration for this paper is drawn from my work experience at Maliganik Tukisiniarvik, one of Nunavut's legal aid clinics. During my time in Iqaluit, I frequently visited the Isumaqsunngittukkuvik Youth Facility, a correctional establishment for young persons. This facility-described by one staff as "a prison, really" - is where I met a young Inuk boy I'll call Michael. Michael had lost contact with his family in one of the territory's more remote communities and his mood seemed to be slipping as the months went by. When asked what he planned to do after his release, Michael explained that he would probably return to Iqaluit - to be incarcerated at the adult facility. This dreadful outlook was reminiscent of narratives I had heard outside Isumaqsunngittukkuvik, where one boy, for instance, would tell me proudly that he did not have a criminal record, yet. It became clear to me that the youth criminal justice system, by trapping juvenile offenders in a vicious circle, was not serving children's interests.

\section{INTRODUCTION}

Having undergone three legislative overhauls in less than a century, Canada's youth justice framework is a testament to the multiple policy objectives and ideological underpinnings at play in the field of juvenile delinquency. In its latest legislation on the matter, the Youth Criminal Justice Act, Parliament explicitly recognizes children's developmental needs and reiterates its adherence to the UN Convention on the Rights of the Child [UNCRC]. ${ }^{1}$ Prominent among the concepts promoted in the UNCRC is the Best Interests of the Child [BIC] principle - the notion that children's interests must be a primary consideration in actions that concern them-outlined in Article 3. To date, however, Canadian courts and policymakers have avoided foregrounding the BIC principle.

Parliament's reluctance to prioritize children's best interests reflects the existence of competing criminal justice concerns. The notion of crime control, which centres on strict and swift punishment at the expense of procedural rights, has long informed state responses to criminality. ${ }^{2}$ More recently, penal populism has emerged as an expression of grassroots discontent with the criminal justice establishment. Offenders, its adherents believe, are unfairly favoured over victims and ordinary citizens while criminality flourishes. ${ }^{3}$ Concepts such as crime control and penal populism advocate for "tough-on-crime" responses to delinquency, including retribution, deterrence and denunciation.

Emphasizing such punitive objectives in the youth justice setting overlooks the importance of promoting children's best interests. Children, by virtue of their dependency, are powerless to shape their own systems and institutions. A response to juvenile delinquency created by adults, according to adult expectations, easily loses sight of children's developmental needs. Beyond honouring Canada's ratification of the UNCRC, commitment to the BIC principle impels policymakers to promote child development and reassess the effectiveness of punitive crime reduction techniques.

Youth Criminal Justice Act, SC 2002, c 1, Preamble.

See Hubert L Packer, "Two Models of the Criminal Process" (1964) 113:1 U Pa L Rev 1.

3 For a detailed description of penal populism, see John Pratt, Penal Populism (New York: Routledge, 2007$)$, chapter 1.

See also Julian V Roberts et al, Penal Populism and Public Opinion: Lessons from Five Countries (Oxford: Oxford University Press, 2003) for an analysis of penal populism's spread in the West. 
This paper calls for a rebalancing of Canadian youth justice so as to prioritize children's best interests. It sketches how Parliament could attribute greater weight to its commitments under Article 3 of the UNCRC, and to the BIC principle in particular. The aim is not to dismiss competing considerations such as public safety and individual accountability. Rather, it is to promote an application of the Youth Criminal Justice Act that centres on the best interests of children.

The article begins by defining the BIC principle in relation to criminal law (Part II). In light of the limited guidance provided by the UNCRC's text, it relies on official UN commentary and doctrinal authorities to describe a multifaceted concept that revolves around child development. An historical overview of juvenile justice reform in Canada then illustrates how children's best interests, once the system's defining feature, have largely yielded to competing concerns such as societal protection and individual accountability (Part III). These observations lead to a review of how the law is applied todaywho makes decisions, who is targeted and how - to explain the Canadian model's nature as a court-based criminal justice system rather than one premised on children's welfare (Part IV). The text then offers a conspectus of practices in Scotland, Scandinavia and Washington state (Part V). Drawing on these select jurisdictions exemplifies how the BIC principle may be reconciled with youth justice despite the dominance of punitive penal discourses. Finally, the paper addresses how to integrate international practices into Canada's legislative framework (Part VI). It argues that policymakers should rebalance applicable sentencing principles so that the child-friendly disposal of cases is not eclipsed by the need for proportionality. If the BIC principle is to gain sufficient support, advocates must address popular concern for public safety and accountability by portraying children's interests not as a standalone concept but rather, from a societal perspective, as part of addressing juvenile delinquency overall.

\section{BEST INTERESTS OF THE CHILD DEFINED}

\section{A. The United Nations Convention on the Rights of the Child}

The UNCRC articulates the BIC principle without providing an explicit definition. It outlines states' general obligation as follows:
Article 3
1. In all actions concerning children, whether undertaken by public or private social welfare institutions, courts of law, administrative authorities or legislative bodies, the best interests of the child shall be a primary consideration. ${ }^{4}$

While Article 3 does not itself define children's best interests, its position within the UNCRC conveys the concept's importance relative to competing considerations. According to the Committee on the Rights of the Child - the body that monitors the UNCRC's implementation-Article 3 is one of the Convention's

4 Convention on the Rights of the Child, 20 November 1989, 1577 UNTS 3 (entered into force 2 September 1990), art 3(1). Articles 3(2) and 3(3) are extensions of the BIC principle in the contexts of state protection and appropriate standards for institutions, respectively. 
general principles. ${ }^{5}$ Not only is the article prominently positioned at the UNCRC's outset, it arguably informs every other provision. Indeed, a number of articles explicitly reference the child's best interests. ${ }^{6}$

Nonetheless, at least in international law, the BIC principle does not displace every competing or complementary concern. When it first appeared in the 1959 Declaration of the Rights of the Child, the concept of children's interests was described as "the paramount consideration" with regard to laws enacted to protect youth and foster their development. ${ }^{7}$ As history would have it, this characterization of the BIC principle did not survive the 11 years of scrutiny and debate that preceded Article 3's adoption. Following an initial draft that preserved the Declaration's phrasing, a number of delegations expressed discomfort with the language. The revised proposal thus read, "the best interests of the child shall be $a$ primary consideration." If there was any doubt that the delegations intended to limit the BIC principle's paramountcy, those suspicions were soon laid to rest. A proposed 1988 amendment to replace the word "a" with "the" failed to garner sufficient support, and the version of the text containing an indefinite article was adopted. ${ }^{9}$

A textual interpretation of Article 3 and its draft versions therefore reveals two of the BIC principle's characteristics. First, the BIC principle is an important concept that underlies the Convention and cannot be assessed on the same footing as all other considerations. Second, children's best interests do not override every competing concern. For a more profound understanding of the BIC principle-especially in relation to crime and juvenile justice — one must turn to the Committee on the Rights of the Child's observations and to academic commentary.

\section{B. The Committee on the Rights of the Child's Comments and Observations}

The Committee on the Rights of the Child is composed of 18 members and oversees state parties' application of the UNCRC. ${ }^{10}$ In executing this function, the body produces general comments regarding select aspects of the Convention, as well as country-specific observations. General comments help clarify the meaning of the UNCRC's text, and individual observations aid in identifying practices that are incompatible with children's best interests.

A comprehensive understanding of Article 3 must reach beyond the provision's wording and recognize the BIC principle's breadth. The principle serves both to ensure the enjoyment of rights outlined in the Convention and to foster children's development on a psychological, social, physical, mental, moral and

5 See Michael Freeman, "Article 3: The Best Interests of the Child" in André Alen et al, eds, A Commentary on the United Nations Convention on the Rights of the Child (Leiden: Martinus Nijhoff, 2007) at 1.

$6 \quad$ With respect to criminal law and punishment, see arts 9 (right against separation from parents), 37(c) (right of children deprived of liberty to be separated from adults) and 40(2)(b)(iii) (right of child accused of infringing penal law to a fair hearing). See also arts 18(1) (common responsibilities of parents), 20(1) (special protection for children deprived of a family environment) and 21 (adoption).

7 See Declaration of the Rights of the Child, GA Res 1386 (XIV), UNGAOR, 14th Sess, Supp No 16, UN Doc A/4354 (1959) 19, Principle 2 [emphasis added].

8 See Freeman, supra note 5 at 25-26 [emphasis added].

$9 \quad$ Ibid at 26.

10 See Office of the United Nations High Commissioner for Human Rights, "Committee on the Rights of the Child" (2016), online: <www.ohchr.org/EN/HRBodies/CRC/Pages/CRCIndex.aspx>. 
spiritual scale. ${ }^{11}$ In addition to promoting youth's holistic development, the BIC principle is concerned with the child's views, vulnerability and identity, as well as preserving the family environment and maintaining relations. ${ }^{12}$ Many, if not all of these considerations, are directly relevant to assessing the youth criminal justice system, especially with respect to deprivations of liberty.

The Committee's general comment on children's rights in juvenile justice provides further guidance on the interaction between the BIC principle and criminal law. Specifically, the Committee notes that protecting children's best interests involves sidelining traditional criminal justice objectives such as retribution and repression in favour of restorative justice and rehabilitation. ${ }^{13}$

Country-specific reports reveal a range of practices that are incompatible with the best interests of children and further illustrate the concept's meaning. The Committee, for instance, expresses concern regarding the UK's use of secure training orders - a form of custodial sentence - on children 12-14 years of age and its incompatibility with Article 3, inter alia. It denounces England, Wales and Northern Ireland's perceived emphasis on punishment and imprisonment. ${ }^{14}$ In its assessment of Egyptian law, the Committee stresses that deprivation of liberty in the context of youth justice should only be used as a last resort. It states that social reintegration, psychological recovery and rehabilitation measures should be prioritized when children are in conflict with the law. ${ }^{15}$

\section{Doctrine and Commentary}

Academic commentators have also attempted to shed light on how the BIC principle informs youth criminal justice, and with good reason. As mentioned, children's interests are but obliquely defined in the UNCRC. Moreover, the concept is expected to act as a benchmark for assessing state parties' laws and practices. ${ }^{16}$ As is to be expected in the literature, disagreement as to the extent and meaning of the BIC principle abounds.

At a minimum, the concept of BIC provides basic protections concerning punishment and mental blameworthiness. According to scholars such as Freeman, children's best interests entitle them to an age of criminal responsibility that reflects their developmental state. ${ }^{17}$ The best interests of children therefore require separation from adults and adult institutions. Subjecting children to ordinary trials where the accused is confronted with a hostile environment and unsympathetic crowds offends societal expectations. The BIC principle also forbids detaining children with adult offenders. ${ }^{18}$

11 See UN Committee on the Rights of the Child, General Comment No 14 on the right of the child to have his or her best interests taken as a primary consideration (art 3, para 1), 29 May 2013, CRC/C/GC/14 at para 4 .

12 Ibid at paras 53-76.

13 See UN Committee on the Rights of the Child, General Comment No 10: Children's Rights in Juvenile Justice, 9 February 2007, CRC/C/GC/10 at para 4b [UNCRC, General Comment No 10]; See also ibid at para 28.

14 See UN Committee on the Rights of the Child, Concluding Observations of the Committee on the Rights of the Child: United Kingdom of Great Britain and Northern Ireland, 15 February 1995, CRC/C/15/Add 15 at para 18.

15 See UN Committee on the Rights of the Child, Concluding Observations of the Committee on the Rights of the Child: Egypt, 18 February 1993, CRC/C/15/Add 5 at para 14. See also UN Committee on the Rights of the Child, Concluding Observations of the Committee on the Rights of the Child: Bangladesh, 18 June 1997, CRC/C/15/Add 74 at para 12 on the incompatibility of Article 3, inter alia, with the incarceration of children in ordinary prisons.

16 See Stephen Parker, "The Best Interests of the Child - Principles and Problems" (1994) 8 Intl JL Pol'y \& Fam 26 at 27.

17 See Freeman, supra note 5 at 55.

18 Ibid at 55-56. 
Other scholars advocate for a more generous reading of the BIC principle. Newell, for instance, argues that subjecting children to criminal sanctions altogether conflicts with Article 3 . He promotes a juvenile justice system that separates and distinguishes responsibility from criminalization. ${ }^{19}$ Children's antisocial behaviour should be assessed and addressed through various forms of diversion, but not through the criminal justice system. Newell finds support for this interpretation of the child's best interests in the International Criminal Court's jurisdiction being limited to persons over the age of $18 .^{20}$

To summarize, children's best interests are a paramount principle, although they cannot displace other considerations altogether. The BIC concept is concerned with youth's holistic development, the preservation of family environments and the maintenance of relations. Prioritizing children's best interests involves sidelining traditional criminal justice objectives and minimizing deprivations of liberty while embracing social reintegration and rehabilitation. A youth justice system that promotes children's best interests also recognizes young persons' reduced mental blameworthiness.

\section{HISTORY OF JUVENILE JUSTICE LEGISLATION IN CANADA}

Modern Canadian youth justice legislation is a patchwork of competing considerations and priorities. Once a prominent feature of the country's juvenile delinquency framework, attention to the child's vulnerability now shares the stage with societal protection and individual accountability concerns. An examination of Canada's legislative history reveals that the values underlying the BIC principle failed to withstand criticism of their effectiveness and calls for a more punitive justice system. Restoring the BIC principle to its former prominence is by no means unfeasible, but it will require that policymakers actively respond to these critiques.

Understanding the evolution of Canada's response to juvenile delinquency involves tracing its development back to the colonial era, before children were granted special protections. At that time, youth were considered mere objects or property rather than subjects of right. ${ }^{21}$ Davis-Barron contends that from Canada's early pioneer times to the mid- $19^{\text {th }}$ century, children were regarded as "miniature adults," a perception that reflected dominant views in Britain and France. As miniature adults, they were subject to the same sanctions as the general population, including hanging, branding and flogging. ${ }^{22}$ By the $19^{\text {th }}$ century, the ideals emanating from the Enlightenment had taken hold and fostered increased attention to the vulnerability and impoverishment of children in pre-Confederation Canada. ${ }^{23}$ Reformers began rallying around the perception that crime and delinquency were a disease. Known then as "child savers," these dissidents focused the debate on providing guidance and treatment. ${ }^{24}$

19 See Peter Newell, "It Is Not Child-friendly to Make Children Criminals" in Said Mahmoudi et al, eds, Child-friendly Justice: A Quarter of a Century of the UN Convention on the Rights of the Child (Leiden: Brill, 2015) 137 at 137.

$20 \quad$ Ibid at 142.

21 See Myriam S Denov, “Children's Rights or Rhetoric? Assessing Canada's Youth Criminal Justice Act and its Compliance with the UN Convention on the Rights of the Child" (2004) 12 Intl J Child Rts 1 at 1 [Denov, "Rhetoric"].

22 See Sherri Davis-Barron, Youth and the Criminal Law in Canada, 2nd ed (LexisNexis, 2015) at 13-14. See also Bryan R Hogeveen, "History, Development, and Transformations in Canadian Juvenile Justice, 1800-1984" in Kathryn M Campbell, ed, Understanding Youth Justice in Canada (Toronto: Pearson, 2005) 24 at 24.

23 See Davis-Barron, supra note 22 at 18.

24 Ibid at 29. 


\section{A. The Juvenile Delinquents Act}

Calls for the special care of children within the criminal justice system did not fall on deaf ears. In 1908, Parliament passed the Juvenile Delinquents Act [JDA]. The Act embraced a parens patriae concept premised on the best interests of the child. Under this model, the court was to step in as a surrogate parent protecting children's welfare and interests when family and school failed to provide proper care. ${ }^{25}$ This welfare approach did not lay blame with the child; it situated delinquency in his or her environment. ${ }^{26}$

Bearing in mind the child's particular needs and vulnerability, the JDA created a number of discrete institutions. These included separate courts and detention facilities, as well as closed trials. ${ }^{27}$ Children were not prosecuted for crimes in the same manner as adults. Instead, a child who violated a provision of the Criminal Code, the laws of the Dominion, province or municipality, or who was guilty of certain vices would be designated a juvenile delinquent. ${ }^{28}$ Accordingly, sentences ranged from fines and supervision to detention in industrial schools. ${ }^{29}$

Despite the Act's welfare approach and commitment to the child's best interests, its effects were frequently not in keeping with modern conceptions of the BIC principle. Under the guise of promoting rehabilitation and treatment, children were often confined for periods far in excess of the equivalent adult sentence. ${ }^{30}$ The JDA's overarching welfare philosophy was arguably committed to control rather than to care. ${ }^{31}$ It should also be noted that the Act did not contain provisions that may today resonate with advocates of the BIC principle, such as restorative justice, community alternatives and diversion.

Ultimately, the JDA's downfall can be traced to calls for additional child protection as well as competing considerations. Many critics of the Act objected to the juvenile justice framework's informality. They decried the indeterminacy of sentences, ${ }^{32}$ the inadequate due process provisions ${ }^{33}$ and, in light of the Charter's constitutional entrenchment, the absence of legal rights. ${ }^{34}$ Explained differently, the insufficiency of children's rights impeded the promotion of children's interests. Others voiced competing concerns. The Act's inability to prevent recidivism echoed growing distrust of the welfare philosophy on which the legislation rested. ${ }^{35}$

25 See Tullio Caputo \& Michel Vallée, “A Comparative Analysis of Youth Justice Approaches” in Roy McMurtry \& Alvin Curling, Review of the Roots of Youth Violence, vol 4, Research Papers (Toronto: Queen's Printer for Ontario, 2008) 207 at 219 ; Ibid at 37.

26 See Denov, "Rhetoric," supra note 21 at 3.

27 See Davis-Barron, supra note 22 at 37.

28 See Gordon West, "Towards a More Socially Informed Understanding of Canadian Delinquency Legislation" in Alan W Leschied, Peter G Jaffe \& Wayne Willis, eds, The Young Offenders Act: A Revolution in Canadian Juvenile Justice (Toronto: University of Toronto Press, 1991) 3 at 6.

29 See Davis-Barron, supra note 22 at 40-41.

30 See Nicholas Bala, "The Development of Canada's Youth Justice Law" in Campbell, supra note 22, 41 at 41 [Bala, "Development"]; Susan A Reid \& Marvin A Zuker, "Conceptual Frameworks for Understanding Youth Justice in Canada: From the Juvenile Delinquents Act to the Youth Criminal Justice Act" in Campbell, ibid, 89 at 90 . See also Lucien Beaulieu, "A Comparison of Judicial Roles under the JDA and YOA" in Leschied, Jaffe \& Willis, supra note 28, 128 at 132 describing actions ostensibly taken for the child's own good as "dispositional paternalism."

31 See Reid \& Zuker, supra note 30 at 99.

32 See Hogeveen, supra note 22 at 36.

33 See Davis-Barron, supra note 22 at 42.

34 See Denov, "Rhetoric," supra note 21 at 4.

35 See West, supra note 28 at 8; Beaulieu, supra note 300 at 134. 


\section{B. The Young Offenders Act}

Criticism of the JDA's ideological grounding and effectiveness culminated in a legislative overhaul. Over 75 years after the first juvenile justice legislation's adoption, the Young Offenders Act [YOA] came into force and replaced the JDA in 1984. The YOA was an attempt at finding a middle ground between the interests of youth and societal protection. ${ }^{36}$ In many respects, the Act appears to have prioritized the latter. Whereas the JDA contained no declaration of principle, the YOA's revealed a clear ranking of priorities. It began by listing the principles of youth accountability and societal protection. A commitment to the minimal infringement of young people's liberty followed, but only when it accorded with the protection of society. ${ }^{37}$

By many accounts, the YOA shifted the focus of Canadian youth criminal justice from a welfare model toward a design more akin to adult criminal law. ${ }^{38}$ In addition to emphasizing accountability and societal protection, the new legislation carved out a greater role for victims of crime. ${ }^{39}$ By way of illustration, the YOA provided for the transfer of cases to adult court based in part on the interests of society. ${ }^{40}$ According to Bala, the Act's dominant objective was holding youth accountable instead of rehabilitation. ${ }^{41}$

The YOA's demise is in large part attributable to a wave of tough-on-crime populism and a belief that the Act was too lenient. During the 1980s, police and media alike fuelled the perception that youth crime was rising even though, in fact, there was no significant increase. ${ }^{42}$ By the 1990 s, Canada witnessed a growing appreciation for the US's punitive responses to juvenile delinquency, perhaps as a result of widespread American cable television availability. ${ }^{43}$ In essence, the tough-on-crime mentality was prevalent throughout the YOA's existence. Denov argues that all three of the Act's major revisions pushed it toward a crime control model. ${ }^{44}$ In fact, every federal party in the 1993 election criticized the YOA for being too lenient. ${ }^{45}$ As it became clear that the $A c t$ 's days were numbered, the federal government released two internal reports detailing potential legislative overhauls. Both documents recommended that societal protection be the principal objective of juvenile justice legislation. ${ }^{46}$

36 See Caputo \& Vallée, supra note 25 at 223.

37 See Young Offenders Act, RSC 1985, c Y-1, s 3, as repealed by Youth Criminal Justice Act, SC 2002 , c 1, s 199.

38 See Caputo \& Vallée, supra note 25 at 223; Bala, "Development," supra note 30 at 42; Reid \& Zuker, supra note 300 at 99.

39 See Denov, "Rhetoric," supra note 21 at 4.

40 See Caputo \& Vallée, supra note 25 at 223.

41 See Bala, "Development," supra note 30 at 43.

42 See Davis-Barron, supra note 22 at 58. While the incidence of police-reported youth crime increased immediately after the YOA's enactment (from about 7,000 incidents per 100,000 population in 1985 to over 9,000 in 1991), this increase mirrored a broader trend in the adult crime rate as well. The rate of youth crime in fact returned to about 7,000 incidents per 100,000 population by the time the YOA was abolished, having declined steadily from 1992 onward: Statistics Canada, "Youth Crime in Canada, 2014" (2016), online: <www.statcan.gc.ca/pub/85-002-x/2016001/article/14309eng.htm>; Statistics Canada, "Police-reported Crime Statistics in Canada, 2016" (2017), online:

$<$ www.statcan.gc.ca/pub/85-002-x/2017001/article/54842-eng.htm>.

43 See Jean Trépanier, "What Did Quebec Not Want? Opposition to the Adoption of the Youth Criminal Justice Act in Quebec" (2004) 46 Can J Corr 273 at 281.

44 See Denov, "Rhetoric," supra note 21 at 5. See also Bala, "Development," supra note 30 at 44 arguing that all three amendments played on the public's fear.

45 See Davis-Barron, supra note 22 at 59.

46 See Caputo \& Vallée, supra note 25 at 228. 


\section{The Youth Criminal Justice Act}

Despite the Youth Criminal Justice Act's [YCJA] adoption stemming largely from a wave of tough-oncrime sentiment, the legislation can be read as reviving concerns for the child's best interests. In this latest youth justice makeover, children are portrayed in a more neutral light. The YCJA abandoned the language of "young offender," which the YOA employed in its title and throughout its substantive provisions, in favour of the term "young person." ${ }^{47}$ This seemingly cosmetic adjustment is in fact telling of a deeper philosophical rebalancing. The YCJA's preamble and listed objectives in many respects deviate from the YOA's emphasis on personal accountability and the protection of society.

Gone is any mention of societal protection as a primary objective of youth criminal justice. ${ }^{48}$ Instead, the Act's preamble opens with a commitment to guiding youth into adulthood. This recognition of the child as a growing being echoes the BIC principle's objective of fostering children's holistic development. Commitment to youth's unique circumstances and developmental needs is reflected in the abolition of transfers to adult courts, which the YOA permitted when society's interests warranted it. The YCJA also explicitly aims to "encourage the repair of harm done to victims and the community" 49 and does so by formalizing and encouraging youth conferences.$^{50}$ It will be recalled that the BIC principle entails scaling back retribution and repression in favour of restorative justice objectives.

One major concern at the time of the YCJA's inception was the widespread use of courts and incarceration in youth matters. Canada, under the YOA, ranked among the Western countries with the highest rates of youth incarceration..$^{51}$ Overuse of custodial sentences is disconcerting for a number of reasons. In addition to isolating youth from their communities - a practice that is in most cases at odds with the BIC principle - conditions inside secure facilities can be detrimental to a child's physical and mental health. Inmate-on-inmate violence and peer abuse are common, often in the form of intimidation, extortion and stealing. ${ }^{52}$ Violence may be initiated or condoned by correctional staff, and many youth do not have anyone to whom they can safely report abuse..$^{53}$

The YCJA's enactment reflected a commitment to reducing reliance on youth courts and incarceration. Section 4 of the Act states that non-judicial proceedings are often the most appropriate and effective means of responding to youth crime.$^{54}$ The preamble, for its part, acknowledges the need to reduce over-reliance on custody for non-violent youth. Accordingly, the YCJA restricts the availability of custodial sanctions to a set of serious situations. Incarceration is only available for violent offences, non-compliance with

47 See Davis-Barron, supra note 22 at 135.

48 Ibid at 136.

49 Youth Criminal Justice Act, supra note 1, s 3(1)(c)(ii).

50 See Department of Justice Canada, The Youth Criminal Justice Act: Summary and Background (Ottawa: Department of Justice Canada, 2013) at 6 [DoJ Canada, Summary].

51 See Clayton C Ruby, Gerald Chan \& Nader R Hasan, Sentencing, 8th ed (Toronto: LexisNexis Canada, 2012), §22.26.

52 See Anthony N Doob \& Carla Cesaroni, Responding to Youth Crime in Canada (Toronto: University of Toronto Press, 2004) at 234-35.

53 See Michelle Peterson-Badali \& Christopher J Koegl, “Juveniles’ Experiences of Incarceration: The Role of Correctional Staff in Peer Violence" (2002) 30 J Crim Justice 41.

54 Encouraging diversion through the use of extrajudicial measures not only advances the BIC principle, it also furthers the country's obligations under the UNCRC's section on penal law. Article 40(3)(a) of the Convention urges the establishment of measures to deal with children accused of crimes without subjecting them to judicial proceedings. 
community sentences, certain instances of recidivism, and so-called exceptional circumstances..$^{55}$ The Act recognizes that youth should not be detained lightly or under the guise of providing rehabilitation. Sections 29(1) and 39(5) concern pre-trial custody and sentencing, respectively, and prohibit incarceration "as a substitute for appropriate child protection, mental health or other social measures." The way Parliament's commitment to reducing court use and rates of incarceration has been carried out in practice is addressed in the following section of this paper.

For all this rebalancing, the YCJA persists in promoting competing considerations. Pre-trial custody, for instance, is geared toward ensuring the accused's attendance in court, protecting the public and maintaining confidence in the administration of justice. Despite acknowledging an over-reliance on incarceration and limiting its use at the sentencing stage, Parliament carried over most of the YOA's provisions on pre-trial custody. ${ }^{56}$ Contrary to the BIC principle, lawmakers also included mechanisms for imposing adult sentences on youth over 14 years of age. ${ }^{57}$ Not only does imposing an adult sentence fail to recognize children's unique developmental needs, it opens the door to additional means of shaming. Youth who receive an adult sentence do not benefit from the protection of publication bans. ${ }^{58}$ It is noteworthy, as well, that the YCJA is intended to recognize the interests of victims, whose concerns may differ sharply from those of an accused child..$^{59}$

This section has traced the legislative history of Canada's youth criminal justice system from a welfare model premised on children's interests to one prioritizing societal protection to its current multifaceted state. It bears mentioning that the YCJA did not restore children's interests to their former prominence. In fact, some would qualify the country's successive juvenile justice acts as part of a progression toward more punitive or crime control models. ${ }^{60}$ Nonetheless, the YCJA and its predecessors reveal that Canadian youth justice is no stranger to the objectives underlying the BIC principle, nor is it averse to promoting them.

\section{CANADA'S YOUTH JUSTICE SYSTEM TODAY}

Fifteen years after its enactment, the YCJA can safely be said to have succeeded in considerably decreasing the use of courts and custody. ${ }^{61}$ Following the $A c t$ 's adoption in 2003, significantly fewer youth accused of crimes have been formally charged by police. From 2000 to 2002, the rate of accused youth who were charged ranged from $56 \%$ to $59 \%$. The following year, the rate fell to $45 \%$ and has remained at or below that level ever since. ${ }^{62}$ The decrease between 2002 and 2003 was even more staggering with

55 See Youth Criminal Justice Act, supra note 1, s 39(1).

56 Ibid at 7.

57 See Youth Criminal Justice Act, supra note 1, s 64(1).

58 Ibid, s 110(2)(a).

$59 \quad$ See DoJ Canada, Summary, supra note 50 at 19.

60 See e.g. Russell Smandych, "Canada: Repenalization and Young Offenders' Rights" in John Muncie \& Barry Goldson, eds, Comparative Youth Justice (London: Sage, 2006) 19.

61 See Nicholas Bala, "Changing Professional Culture and Reducing Use of Courts and Custody for Youth: The Youth Criminal Justice Act and Bill C-10" (2015) 78 Sask L Rev 127 at 127 [Bala, "Changing Professional Culture"].

62 See Statistics Canada, "Youth Crime in Canada, 2014," supra note 422 The decrease in youth being formally charged had a ripple effect on the number of youth being processed and sentenced before the courts. 
respect to certain specific offences such as property crimes (from $52 \%$ to $38 \%$ ) and cannabis possession (from $43 \%$ to $24 \%$ ) ${ }^{63}$ The courts also heeded Parliament's commitment to diminishing the use of custody. Between 2002/2003 and 2014/2015, the rate of guilty youth cases receiving custodial sentences fell from $27 \%$ to $15 \%{ }^{64}$ Despite these decreases, Canada continues to process youth through formal justice mechanisms and to rely on incarceration to a greater extent than several Western countries. ${ }^{65}$ In many respects, Canada's response to youth crime still operates according to a traditional court-based model.

The YCJA confers jurisdiction over any "young person" alleged to have committed a criminal offence. A young person is defined as being at least 12 but less than 18 years of age. ${ }^{66}$ Children under 12 years old are not deemed to have reached the age of criminal responsibility; their actions are not subject to criminal sanctions.

Not all young persons who are apprehended by police are processed through the courts. Diversion is available under the umbrella of extrajudicial measures, which the YCJA defines as "measures other than judicial proceedings under this Act used to deal with a young person alleged to have committed an offence. ${ }^{, 67}$ Extrajudicial measures include taking no further action, warnings, cautions, and voluntary referrals to community programs or agencies. ${ }^{68}$ They also include extrajudicial sanctions, such as volunteer work and compensation to the victim. Whereas other forms of extrajudicial measures serve as an alternative to laying charges, extrajudicial sanctions are also available after charges have been laid. ${ }^{69}$

Under the YCJA, pre-adjudication diversion is both available and encouraged in a number of situations. Section 4(c) of the Act creates a presumption that extrajudicial measures are adequate for youth who commit a non-violent offence and do not have any previous convictions. Similarly, s. 6 directs police officers, before they commence judicial proceedings, to consider whether taking no further action, administering a warning or a caution, or referring the youth to a program or agency would be sufficient.

However, the decision to divert a young person remains discretionary. Failure by a police officer to consider the diversion mechanisms discussed above cannot invalidate any subsequent charges. ${ }^{70}$ The Act also specifies that nothing in the provisions concerning extrajudicial sanctions prevents laying an information or proceeding with the prosecution of an offence. ${ }^{71}$ Under the YCJA, there is no right to diversion.

Youth cases that are not diverted proceed through the courts, before a judge. In Canada, youth court matters are generally processed by the same judges who hear adult cases. In fact, youth court judges are not required to have any particular training or background under the YCJA. ${ }^{72}$ Authors such as Bala and

63 Ibid.

64 See Statistics Canada, "Youth Court Statistics in Canada, 2014/2015" (2016), online: <www.statcan.gc.ca/pub/85-002$\mathrm{x} / 2016001 /$ article/14656-eng.htm $>$. As it has been since the early 1990s, probation is the most common sentence imposed by the courts.

65 See Nicholas Bala \& Sanjeev Anand, Youth Criminal Justice Law, 2nd ed (Toronto: Irwin Law, 2009) at 677-78.

66 See Youth Criminal Justice Act, supra note 1, s 2(1).

67 Ibid, s 2(1).

68 See Department of Justice Canada, "Extrajudicial Measures," online: <www.justice.gc.ca/eng/cj-jp/yj-jj/toolsoutils/sheets-feuillets/pdf/measu-mesur.pdf $>$.

69 Ibid.

70 See Youth Criminal Justice Act, supra note 1, s 6(2).

71 Ibid, s 10(6).

72 See Bala \& Anand, supra note 65 at 175-76; 179. 
Anand have expressed concern that judges who hear youth matters may not approach a young person's case any differently than they would an adult's. ${ }^{73}$ In essence, there is no guarantee that a young person will appear before a judge who specializes in youth justice or is particularly versed in children's best interests.

When a case is before the courts, the judge may attempt to gain a better understanding of the child's needs and interests by involving the local welfare authorities. Section 35 of the YCJA provides that a youth justice court may "refer the young person to a child welfare agency for assessment to determine whether the young person is in need of child welfare services." This statutory provision has its limits. Referring the child for assessment does not discontinue the judicial proceeding, and the judge cannot order the welfare agency to become involved..$^{74}$ Moreover, the request for assessment may be of little use in practice. At least one youth court judge reports that, in his experience, invoking s.35 merely involves sending a letter to the relevant child welfare agency inquiring about the services it can provide the youth. ${ }^{75}$ Since the judge cannot order treatment or terminate the judicial proceedings, a youth who is found guilty will be sentenced according to the YCJA's provisions.

Sentencing under the YCJA is different from the adult model. Although the Act includes some of the sentencing principles listed in the Criminal Code ${ }^{76}$ youth sentences are not determined by discounting the sanction an adult would receive, for instance. The YCJA recognizes children's diminished moral blameworthiness and culpability. ${ }^{77}$ At a minimum, s.38(2)(a) holds that sentences "must not result in a punishment that is greater than the punishment that would be appropriate for an adult who has been convicted of the same offence committed in similar circumstances."

That is not to say that the harshest youth sentences cannot resemble those that are meted out to more mature offenders. While youth who are committed to custody must be held apart from adults ${ }^{78}$ they can nonetheless be incarcerated in similar conditions. Like adults, youth can have their access to the community denied or restricted by being held in secure facilities, which feature perimeter fencing, locked doors, electronic surveillance and close staff supervision. ${ }^{79}$ At this juncture, it bears mentioning that the YCJA's distinct sentencing principles and available sentences is a vast topic. Aside from noting Canada's comparatively widespread use of custody and its potential for adult-style incarceration, an assessment of available sentences is beyond the scope of the present analysis.

The YCJA's measures to limit judicial proceedings, preserve the family environment, and maintain relations are therefore restricted by their place in a traditional court-based model. A survey of practices abroad illustrates how certain jurisdictions have adapted similar models to prioritize the BIC principle.

\footnotetext{
Ibid at 179.
}

74 See Bala, "Changing Professional Culture," supra note 61 at 157.

75 See Ross Green, "Where the Systems Collide: Youth Court, Child Protection, Interdisciplinary Approaches, and Section 35 Reports" 19 Can Crim L Rev 21 at 23.

76 See Criminal Code, RSC 1985, ss 718.1-718.2.

77 See Youth Criminal Justice Act, supra note 1, s 3(b).

$78 \mathrm{Ibid}, \mathrm{s} 84$.

79 See Ontario Ministry of Children and Youth Services, "Custody Sentencing" (2016), online:

$<$ www.children.gov.on.ca/htdocs/English/youthandthelaw/sentence/custody-sentence.aspx >; McCreary Centre Society, "Voices from the Inside: Next Steps with Youth in Custody" (2007), online:

$<\mathrm{http}: / / \mathrm{mcs}$. bc.ca/pdf/voices_from_the_inside_web.pdf $>$ at 8 . 


\section{CHILD-FRIENDLY PRACTICES IN SELECT JURISDICTIONS}

The following section offers an exposé of youth justice in Scotland, Scandinavia and Washington state. These jurisdictions were selected because of their similar histories with respect to juvenile justice and the adaptability of their approaches to the Canadian setting. The objective is twofold. First, the section highlights methods of prioritizing the BIC principle, such as mandatory diversion to social services, reduced criminal responsibility and strict limits on incarceration. Through these means of responding to juvenile delinquency, the selected jurisdictions echo the BIC principle's aims of preserving relations, fostering development and providing rehabilitation. Second, this section illustrates how governments have maintained child-friendly systems in spite of punitive penal rhetoric.

\section{A. Scotland}

The Social Work (Scotland) Act 1968 marked a revolutionary shift in Scottish juvenile justice by introducing children's hearings - a system in which committees assess the needs but not the deeds of youth in conflict with the law. Prior to the hearings system's implementation, the processing of delinquent youth fell under the purview of criminal courts. ${ }^{80}$ By the latter half of the $20^{\text {th }}$ century, however, criticism regarding the treatment and care of juveniles was mounting. The Secretary of State for Scotland commissioned a report to study these issues with particular attention to court powers and procedures. ${ }^{81}$

The ensuing Kilbrandon Report attributed dissatisfaction with juvenile courts to the ambitious expectation that they act as criminal tribunals while simultaneously dispensing treatment and education. ${ }^{82}$ At the core of the Report's recommendations was an understanding that differences between juvenile offenders and youth requiring protection or care were of little significance. No distinction could be drawn so as to justify discrete modes of treatment. ${ }^{83}$ Kearney summarizes the Kilbrandon Report's observations in two revolutionary proposals: "separation of 'trial' from disposal and declaring the needs of the child to be the central principle of disposal." 84 These recommendations were promptly adopted in the Social Work (Scotland) Act 1968 and came into force in 1971.

Concern for children's interests is not new in Scottish juvenile justice. For decades, the Children and Young Persons (Scotland) Act 1937 mandated criminal courts to consider delinquent children's welfare. What is revolutionary today is that a single tribunal having at its disposal a single set of remedies processes all children in need of help, including those accused of committing crimes ${ }^{85}$ Children can find themselves before a hearing panel for a host of reasons, only one of which is the commission of an offence. When this occurs, the Children's Hearings (Scotland) Act 2011 provides that decision makers are to "regard the need to safeguard and promote the welfare of the child throughout the child's childhood as the paramount

80 See Lesley McAra, "Welfare in Crisis? Key Developments in Scottish Youth Justice" in Muncie \& Goldson, supra note 60,127 at 128 .

81 See Committee on Children and Young Persons, Children and Young Persons, Scotland: Report by the Committee Appointed by the Secretary of State for Scotland (Edinburgh: Her Majesty's Stationary Office, 1964) (Chair: Lord Kilbrandon) at para 1 [Kilbrandon Report].

82 Ibid at para 71.

83 Ibid at paras $13,15$.

84 See Brian Kearney, The Scottish Children's Hearings System in Action (Edinburgh: Tottel, 2007) at xxvi.

85 See Kenneth McK Norrie, Children's Hearings in Scotland, 2nd ed (Edinburgh: W Green, 2005) at 2. 
consideration." 86 It is noteworthy that the provision arguably exceeds the state's obligation under Article 3 of the UNCRC by identifying the child's welfare as the paramount consideration.

The ultimate purpose of a children's hearing is determining whether to impose a compulsory supervision order. A supervision order contains one or more oversight measures and identifies the local authority that will be responsible for implementing them. ${ }^{87}$ The measures can include restrictions on where the child will reside, limits on contact between the child and certain persons, and specified duties in relation to the child which the local authority must discharge. ${ }^{88}$ Compulsory supervision orders can last no more than one year or until the child's $18^{\text {th }}$ birthday, whichever comes first, although they can be renewed. ${ }^{89}$

Determining whether to impose a supervision order involves multiple steps. Once referred for a hearing, often by police, the child's case is assigned to a reporter. The reporter is a government employee tasked with assessing whether grounds for a hearing exist and a supervision order is necessary. ${ }^{90}$ In practice, reporters usually have training in either social work, legal studies, or both. ${ }^{91}$ Despite the reporter's assessment, whether to impose a supervision order is decided at the hearing. A children's hearing is composed of three volunteers who, ideally, are familiar with the child's local environment. ${ }^{92}$ Therefore, unlike under the Canadian model, the decision-makers are reporters specializing in children's needs and volunteers with knowledge of the child's surroundings. They are not criminal judges. It bears repeating that hearings are not criminal proceedings. The panel is asked to examine the child's needs, not to establish guilt..$^{93}$

Scotland's hearings model offers numerous avenues for diversion. Evidently, the system itself is a form of legislated diversion from the type of youth courts that exist in Canada. Yet, the model is also compatible with current Canadian discretionary diversion practices in that each actor is afforded opportunities to resolve cases according to the child's interests. Scottish police officers may, for instance, issue a formal warning instead of subjecting the youth to a prolonged hearing process. ${ }^{94}$ After receiving a referral, the reporter may also decline to proceed with a hearing if he or she believes a compulsory supervision order is not required ${ }^{95}$ or is satisfied an existing order is sufficient to address the child's needs. Finally, as mentioned, the hearing panel is also free not to impose a supervision order despite the reporter's opinion that such a measure is warranted.

The children's hearings model provides a means of countering the criticism Canada's juvenile justice system faced when it too adopted a predominantly welfare-based approach. It will be recalled that the JDA, and its potentially indeterminate sentences in particular, were seen as coercive treatment ostensibly

86 Children's Hearings (Scotland) Act 2011, asp 1, s 25 [Children's Hearings Act].

87 Ibid, s 38(1).

88 Ibid, $\mathrm{s} 83(2)$.

$89 \quad$ Ibid, s 83(7).

$90 \quad$ Ibid, $\mathrm{s} 66$.

91 See Kearney, supra note 84 at xxvii.

92 See Norrie, supra note 85 at 3; Children's Hearings Act, supra note 86, ss 5-6.

93 See Michele Burman et al, "The End of an Era? - Youth Justice in Scotland" in Josine Junger-Tas \& Scott H Decker, eds, International Handbook of Juvenile Justice (New York: Springer, 2008) 439 at 442.

$94 \quad$ Ibid at 456.

95 See Children's Hearings Act, supra note 8686, s 68 
justified by the BIC principle. Scotland has responded to this criticism by emphasizing minimal intervention. Hearing panels are statutorily prohibited from imposing an order unless "it would be better for the child if the order [...] were in force than not." ${ }^{.96}$ Explained differently, compulsory state intervention is limited to instances where the panel is persuaded that it is necessary for the child ${ }^{97}$ As mentioned, supervision orders are also subject to strict temporal limits.

A model like Scotland's further mitigates the potential harm of compulsory intervention by restricting the use of custody and promoting voluntary treatment. ${ }^{98}$ The notion of voluntary treatment figures prominently in the Scottish system. Once a reporter determines that compulsory measures are not required, he or she may suggest any number of optional support initiatives. Burman et al suggest that such initiatives have a greater chance of success as children and their families will benefit more substantively from treatment they have elected to undertake. ${ }^{99}$ Similarly, where the hearing panel does not impose supervision and the child is discharged, he or she will be entitled to six months' rehabilitation. ${ }^{100}$

Scotland's juvenile justice model also provides lessons on maintaining a system that prioritizes the BIC principle in an era of penal populism. On the one hand, advocates of children's interests must promote the existing framework. Maintaining support in Scotland has required making demonstrable improvements to the system's effectiveness and communicating the hearings model's success to the public. ${ }^{101}$ On the other hand, amendments made as political concessions should be carefully imbedded in the legislation's broader philosophy. By way of example, the children's hearings model now permits certain exceptional cases being tried in court when alternative measures have been exhausted. Yet, such proceedings still contain mechanisms for the courts to consult the children's hearing - sometimes compulsorily - on which sentence to impose, if any. ${ }^{102}$ Furthermore, while not the paramount concern in these exceptional cases, safeguarding and promoting the child's welfare remains a primary consideration. ${ }^{103}$ It is through such measures that the children's hearings model remains committed to Lord Kilbrandon's recommendations, despite a trend toward punitive justice in many developed countries. ${ }^{104}$

\section{B. Scandinavia}

From a Canadian perspective, the Scandinavian model may amount to a less ambitious change than the Scottish hearings concept. In fact, Scandinavia does not have a youth justice system per se. Instead, these countries have established a comparatively advanced age of criminal responsibility. ${ }^{105}$ Unlike Scottish or Canadian children, Scandinavian youth under the age of 15 are not subject to the criminal law. As for

$96 \quad$ Ibid, s 28(2).

97 See Children's Hearings Scotland, Practice and Procedure Manual (Edinburgh: Children's Hearings Scotland, 2013) at 18 .

98 See Hazel Croall, "Criminal Justice in Post-devolutionary Scotland" (2006) 26:3 Critical Social Policy 587 at 590.

99 See Burman et al, supra note 93 at 460.

100 See Norrie, supra note 85 at 131.

101 See Nico Juetten, "Enough of 'Tough': Youth Justice in Scotland" (2009) 16:3 Public Policy Research 180 at 184.

102 See Norrie, supra note 85 at 149.

103 See Children's Hearings Act, supra note 86, s 26.

104 See Croall, supra note 98 at 601.

105 See Anette Storgaard, "Juvenile Justice in Scandinavia" (2005) 5:2 J Scandinavian Studies Criminology \& Crime Prevention 188 at 189. 
delinquent children over 15, they are processed through regular adult courts, where judges apply special considerations to reflect their level of development. Despite their differences in other respects, Scandinavian countries have followed a similar legislative path with regard to youth justice so as to allow a joint analysis of their laws. ${ }^{106}$

Swedish juvenile justice history is representative of Scandinavia's longstanding emphasis on children's interests in criminal law. As they did in Canada, ideas left over from the Enlightenment helped shape policy outlooks in Sweden and promote the interests of children regardless of whether they conflicted with those of their parents. ${ }^{107}$ By 1902, the country passed legislation to remove all sanctions from the penal code for children under 15 and reduce punishment for older children. ${ }^{108}$ Prison sentences for youth under 15 were replaced with "forced care." 109 As was the case with the JDA in Canada, legislative drafters intended to reflect children's interests but appeared insensitive to the damage compulsory interventions could cause. ${ }^{110}$ The legislature addressed this shortcoming after World War II by abolishing forced care in favour of deinstitutionalization. ${ }^{11}$ The push against involuntary treatment in institutions was emblematic of the political climate in other Nordic countries between 1960 and $1990 .{ }^{112}$ Over a century after its creation, the Scandinavian model of juvenile justice premised on children's welfare persists today.

Since they cannot be held criminally responsible for their acts, delinquent children under 15 years of age are referred to social services agencies. The agencies' mandate is not to punish; they are tasked with devising a suitable response to criminal acts solely according to the child's social situation. ${ }^{113}$ Social services agencies have at their disposal the same support resources to address criminality as they do for substance abuse or issues in the home. ${ }^{114}$

Despite trying children over the age of 15 in adult courts, Scandinavian countries have maintained protections that recognize this age group's unique needs and interests. One noticeable feature is the more robust inclusion of welfare authorities than the judge's optional referral power under s.35 of the YCJA. Many Scandinavian countries require social welfare agencies to be notified and invited to participate in the youth justice process, often as early as the investigative stage. ${ }^{115}$ Moreover, clear guidelines exist at the sentencing stage to ensure youth receive a more lenient sanction than would an adult in the same situation. For instance, a child under 18 can expect a custodial sentence that is half that of an adult convicted of an identical crime. ${ }^{116}$ It is also noteworthy that Scandinavian countries have a more inclusive definition of youth than many jurisdictions. Although they do not enjoy the same treatment as their younger counterparts, youth aged 18-20 cannot be punished as harshly as adults. ${ }^{117}$

106 See Caputo \& Vallée, supra note 25 at 277.

107 See Carl-Gunnar Janson, "Youth Justice in Sweden" (2004) 31Crime \& Justice 391 at 396.

108 Ibid at 395.

109 See Jerzy Sarnecki \& Felipe Estrada, "Keeping the Balance between Humanism and Penal Punitivism: Recent Trends in Juvenile Delinquency and Juvenile Justice in Sweden" in Junger-Tas \& Decker, supra note 93, 473 at 474.

110 See Janson, supra note 10707 at 397.

111 See Sarnecki \& Estrada, supra note 109 at 474.

112 See Tapio Lappi-Seppälä, "Finland: A Model of Tolerance?" in Muncie \& Goldson, supra note 60, 177 at 178.

113 See Sarnecki \& Estrada, supra note 109109 at 494.

114 See Storgaard, supra note 10505 at 195.

115 Ibid.

116 See David Shannon et al, Youth and Crime in Sweden (New York: Oxford University Press, 2014) at 9.

117 Ibid. 
Low rates of incarceration are another hallmark of Scandinavian juvenile justice. The BIC principle, it will be recalled, is interpreted as restricting carceral sentences to the rarest of situations. Finland offers a powerful example of how to achieve this objective. During the early 1950s, the country's prisoner rate was four times greater than that of its Nordic neighbours. ${ }^{118}$ Finland responded to its perceived overuse of incarceration through extensive sentencing reforms. It reduced the penalties for property offences and limited the impact of prior convictions while simultaneously expanding the scope of non-custodial sanctions, such as community service and suspended sentences. Importantly, the changes did not adversely affect Finland's crime rate ${ }^{119}$ The reductions in incarceration were felt most heavily in the youth prison rates, since young persons are typically the perpetrators of property offences and recidivism is common among younger age groups. ${ }^{120}$ Today, only $1 \%$ of convicted youth receive prison sentences. ${ }^{121}$ Finland's youth prison population is correspondingly low, at about $0.2 / 100,000$ children. ${ }^{122}$ By way of comparison, the Canadian youth prison population is $60 / 100,000$ children. ${ }^{123}$ Countries in Scandinavia therefore emphasize the BIC principle by limiting sentences that disrupt children's development to a very select set of cases.

Scandinavian countries have not escaped popular criticism of child-friendly approaches to crime. Since its very beginnings in Sweden, the treatment ideology attracted claims that it was an ineffective criminal deterrent and insufficiently punitive. ${ }^{124}$ Scandinavia has countered the former criticism, according to which prioritizing children's interests is ineffective, through research justifying its approach. ${ }^{125}$ As for the charge that responses are too lenient, the answer, like Scotland's, has been careful political compromise. In Denmark, the legislature introduced youth contracts - a special condition when charges are withdrawn that enjoins the parents to partake in specific actions. ${ }^{126}$ By laying additional court-sanctioned responsibilities on the youth's parents, policymakers managed to assuage public discontent without compromising children's interests.

\section{Washington State}

The United States is not generally a model for promoting the BIC principle in criminal law. Over the last decade, the country has espoused a largely punitive and retributive approach to juvenile justice. ${ }^{127}$ It also bears mentioning, particularly given that this paper advocates for greater emphasis on Article 3, that

118 See Lappi-Seppälä, supra note 112 at 179.

119 Ibid at 178-179.

120 Ibid at 180 .

121 Ibid at 186.

122 See Noetic Solutions Pty Limited, "Review of Effective Practice in Juvenile Justice" (2010), online: $<$ www.juvenile.justice.nsw.gov.au/Documents/Juvenile\%20Justice\%20Effective\%20Practice\%20Review\%20FINAL.pd $\mathrm{f}>$ at 7 [Noetic].

123 See Statistics Canada, "Youth Correctional Statistics in Canada, 2014/2015" (2016), online: <www.statcan.gc.ca/pub/85002-x/2016001/article/14317-eng.htm > (the province with the lowest rate, British Columbia, stands at 20/100,000 while the province with the highest rate, Manitoba, registers at 260/100,000).

124 See Sarnecki \& Estrada, supra note 109 at 475.

125 Ibid at 499.

126 See Storgaard, supra note 105 at 196.

127 See Donna M Bishop \& Scott H Decker, "Punishment and Control: Juvenile Justice Reform in the USA" in Junger-Tas \& Decker, supra note 93, 3. 
America has not ratified the UNCRC. Washington state itself may not be a prime example of best practices. It does not openly acknowledge a commitment to the BIC principle and values holding young offenders accountable as much as rehabilitating them. ${ }^{128}$ Nonetheless, at a time when the United States leans so heavily toward punitive responses to youth crime, Washington exemplifies the means of defending child-friendly initiatives.

Americans have a long history of separate juvenile justice provisions. Originally, these were enacted to protect children from the corrupting influences of advanced adult offenders and to provide them with the requisite treatment to transition through adolescence. ${ }^{129}$ Concern that young offenders were more akin to neglected or dependent children than mature criminals prompted the establishment of juvenile courts in Washington as early as $1905 .{ }^{130}$ After an initially positive reception, youth courts themselves came under fire in the latter half of the $20^{\text {th }}$ century. Fuelled in part by the popularity of labelling theory and similar schools of thought in the social sciences, skepticism mounted concerning courts' ability to respond to youth issues. ${ }^{131}$

The 1970s brought a short-lived wave of deinstitutionalization across the United States. At that time, Massachusetts boldly closed all of its secure youth corrections facilities and shifted its attention to community-based alternatives. Over the following years, a number of politically diverse states began emulating Massachusetts to varying degrees. ${ }^{132}$ By the mid-1990s, however, a small group of criminologists and political scientists forecasted that a new generation of juvenile "super predators"born to drug-addicted parents and raised without religion or employment - was coming of age. ${ }^{133}$ The predictions caused a moral panic, despite a lack of supporting scientific evidence. Frightened by the prospect of increased criminality, many American policymakers soon retreated to a punitive and retributive approach. ${ }^{134}$

For its part, Washington held on to the orientation it had developed toward youth justice throughout the $20^{\text {th }}$ century. Having enacted its Juvenile Justice Act in 1977, the state passed additional legislation in the 1980s to integrate youth justice with welfare services. ${ }^{135}$ In so doing, it took steps to consolidate youth justice, mental health and child welfare services, as well as to improve cross-agency information sharing. ${ }^{136}$ Today, efforts to integrate child welfare services remain a prominent feature of Washington's approach to juvenile delinquency.

128 See Todd Dowell, “The Juvenile Offender System in Washington State: 2015 Edition” (2015), online:

$<$ http://70.89.120.146/wapa/materials/Understanding\%20the\%20Juvenile\%20System\%20in\%20WA\%202015\%20Editio n.doc $>$ at 1 .

129 See Bishop \& Decker, supra note 12727 at 3.

130 See Dowell, supra note 12828 at 1.

131 See Barry Krisberg, "Rediscovering the Juvenile Justice Ideal in the United States" in Muncie \& Goldson, supra note 60, 6 at 7.

132 Ibid at 10.

133 See e.g. John J Dilulio, “Crime in America: It's Going to Get Worse" (1995) Reader's Digest, 55; John J Dilulio, "They're Coming: Florida's Youth Crime Bomb" (1996) Spring Impact, 25; James Q Wilson, "Crime and Public Policy" in James Q Wilson and Joan Petersilia, eds, Crime (San Francisco: Institute for Contemporary Studies Press, 1995), 489.

134 See Krisberg, supra note 131 at 11.

135 See RCW tit $13 \S 13.06$ [Consolidated Juvenile Services Programs].

136 See Jason Ziedenberg, Models for Change: Building Momentum for Juvenile Justice Reform (Justice Policy Institute, 2006) at 26. 
The legislature also promotes the BIC principle's developmental component by limiting children's interactions with criminal justice mechanisms. In Washington, diversion is not only encouraged, as it is under the YCJA; it is sometimes required. Prosecutors are statutorily obligated under the state's Juvenile Justice Act of 1977 to divert certain first time offences. ${ }^{137}$ The fact that these offences include prostitution and other acts with exploitative overtones speaks to the legislature having an eye to protecting vulnerable youth.

In an American political climate so dominated by punitive discourse, Washington has had to justify its comparatively child-friendly policies. A portion of this justification is done through heavy reliance on evidence-based responses to juvenile delinquency. The Washington State Institute for Public Policy, a body developed by the legislature, conducts nonpartisan research that can be used to defend less punitive approaches. In addition to providing data with regard to recidivism and delinquency, the Institute performs cost-benefit analyses. ${ }^{138}$ In fact, a number of community-based alternatives to incarceration are promoted on economic efficiency grounds. The Community Juvenile Accountability Act $t^{139}$ and the Juvenile Detention Alternatives Initiative - two enterprises geared toward preventing youth imprisonment - are justified on economic grounds. ${ }^{140}$ While the state stops short of placing children's interests ahead of competing considerations, Washington does exemplify how to promote the BIC principle in a country that is arguably the developed world's most stringent adherent of penal populism.

\section{OVERCOMING CANADA'S RELUCTANCE TO PRIORITIZE THE BIC PRINCIPLE}

\section{A. The Call for Reform}

There are a number of reasons to adopt foreign practices regarding the BIC principle, not the least of which is enabling Canada to comply more fully with its international commitments. As mentioned above, the YCJA's preamble underlines Canada's ratification of the UNCRC and endorses children's particular rights and freedoms. Yet, the Act's balancing of competing considerations arguably fails to reflect the Convention's provisions on children's best interests. Whereas Article 3 stipulates that a child's best interests must be a primary consideration in all actions concerning children, the Act places considerable weight on the principles of societal protection and individual accountability. In a piece assessing Canadian juvenile justice's compliance with the UNCRC, Denov observes that "[t]he fact that the YCJA does not have the child's best interests as one of its guiding principles and that it continues to erode the boundaries between the youth and adult criminal justice systems demonstrates inadequate compliance to the

137 See RCW tit 13 § 40.070(6)-(7) [Juvenile Justice Act of 1977].

138 See Ziedenberg, supra note 135 at 26. See also the Institute's website: online, <www.wsipp.wa.gov/PolicyAreas>.

139 RCW tit $13 \S$ 13.40.500-13.40.540 [Community Juvenile Accountability Act].

140 See Janet K Wiig \& John A Tuell with Jessica K Heldman, Guidebook for Juvenile Justice \& Child Welfare System Coordination and Integration: A Framework for Improved Outcomes, 3rd ed (Robert F Kennedy Children's Action Corps, 2013) at 74; Governor's Juvenile Justice Advisory Committee, "The Juvenile Justice Detention Alternatives Program: A Successful Start in Washington" (2009), online:

$<$ www.dshs.wa.gov/sites/default/files/JJRA/pcjj/documents/JDAIPolicyBrief3-11-09.docx>. On the merits of promoting evidence-based policies generally, see Richard E Redding, "Lost in Translation No More: Marketing Evidence-Based Policies for Reducing Juvenile Crime" in Nancy E Dowd, ed, A New Juvenile Justice System: Total Reform for a Broken System (New York: NYU Press, 2015) 139. 
Convention." ${ }^{141}$ At the very least, even if the YCJA does not contravene the UNCRC, reforms would enable the $A c t$ to reflect Canada's international commitments more faithfully.

Setting aside the UNCRC, there are important policy reasons for prioritizing the BIC principle. Children, by virtue of their age and mental development, are more vulnerable than adults. With little say in how decisions are made, there is a real danger that children's interests will be ignored if not brought to the fore. ${ }^{142}$ By the same token, society must afford children the opportunity to grow into successful adults. Supporting institutions that cater to youth's development is therefore incumbent on everyone. Parents, and one could argue society more broadly, are responsible for bringing children into the world. As such, they adopt a responsibility that is implicit in parenthood, namely sacrificing one's own interests for those of their children. ${ }^{143}$

Attributing further weight to the BIC principle also corresponds with downscaling less effective approaches to crime reduction. To the extent that prioritizing children's best interests is synonymous with discouraging incarceration and promoting diversion, it presents a tenable method for deterring repeat offending. Data from the United States and Canada challenge the effectiveness of traditional crime control interventions. In an American meta-analysis of 29 experiments conducted over a 35-year span, Petrosino, Turpin-Petrosino and Guckenburg reported that formal processing through the juvenile justice system increases rather than decreases criminality. ${ }^{144}$ Similarly, Kijewski's study of Canadian youth suggests that formal processing through youth courts does not deter recidivism. ${ }^{145}$ The study paired 71 youths who were only cautioned by police following the commission of an offence with 71 youths who were charged and appeared in court. The matching accounted for age, sex, previous police contact and severity of the offences, all of which were committed in the same year. Kijewski found no significant difference between each group's likelihood of reoffending, with youth who were only cautioned having slightly fewer subsequent contacts with police. The data did not support the notion that attending court deters youth from reoffending. ${ }^{146}$

An Australian study by Kraus on the use of short sharp shocks (i.e. brief, severe punishment) casts further doubt on the effectiveness of incarcerating youth. ${ }^{147}$ Kraus matched 90 juvenile first offenders who were remanded in custody with 90 juvenile first offenders who were remanded at home instead. Each offender was male and subsequently received a sentence of probation. The pairing was done according to age, the court in which the youth appeared, and the number and type of charges. Kraus concluded that considerably more of the youth who had been remanded in custody reoffended. As for those who did

141 Myriam S Denov, "Children's Rights, Juvenile Justice, and the UN Convention on the Rights of the Child: Implications for Canada" in Campbell, supra note 22, 65 at 80-81.

142 See Freeman, supra note 5 at 40.

143 See $i b i d$.

144 See Anthony Petrosino, Carolyn Turpin-Petrosino \& Sarah Guckenburg, "Formal System Processing of Juveniles: Effects on Delinquency" in US Department of Justice, Crime Prevention Research Review, No 9 (Washington, DC: US Department of Justice, 2013).

145 See Kristina J Kijewski, "The Effect of the Decision to Charge Upon Subsequent Delinquent Behaviour" (1983) 25 Can J Crim 201.

146 Ibid at 202-204, 206.

147 See J Kraus, "Remand in Custody as a Deterrent in Juvenile Jurisdiction" (1978) 18:3 Brit J Crim 285. 
recidivate, the pattern, frequency and seriousness of offending were no different between the groups. ${ }^{148}$ Evidently, Canada's comparatively heavy reliance on formal court processing and incarceration is at odds with research on the effectiveness of those crime reduction approaches.

\section{B. Confronting Penal Populism}

Managing criminality is a politically contentious issue. In a number of Western countries, tough-oncrime approaches that promote strict and swift punishment resonate strongly with the electorate. ${ }^{149}$ Canada is no exception to this trend. It will be recalled that the YCJA was ushered in by a wave of tough-on-crime populism reflecting dissatisfaction with the YOA's perceived leniency. This sentiment did not subside after the new Act's adoption, and politicians continue to engage with the electorate's concern and apprehension. ${ }^{150}$

Approaches to crime suppression that champion retribution over accused persons' rights are decidedly incompatible with the BIC principle. Their emphasis on punishment displaces goals such as fostering youths' holistic development, preserving relations and maintaining a family environment. The BIC principle can only be meaningfully prioritized if tough-on-crime rhetoric loses its political traction.

Tackling widespread penal populism requires promulgating the basic concept of children's best interests. The Committee on the Rights of the Child has expressed concern that the BIC principle is not widely known in Canada. ${ }^{151}$ Support for children's best interests can hardly be expected to grow if the general public is not alive to the concept. Moreover, proponents must publicize the abovementioned benefits and motivations for prioritizing the BIC principle, namely honouring international human rights commitments, responding to children's developmental needs and downscaling ineffective alternative crime reduction approaches.

Canadian policymakers and interested parties can justify child-friendly criminal justice initiatives by drawing on examples from Scotland, Scandinavia and Washington. Most importantly, a framework centred on children's best interests must be perceived as effective. All three jurisdictions exemplify the need to conduct ongoing research and to tout their model's efficacy. As the United States demonstrates, the BIC principle's success can even be quantified in economic efficiency terms.

Examples from foreign jurisdictions also speak to the importance of careful political compromise. Responding to the public's desire for accountability or punishment should not be done by introducing independent punitive provisions. Rather, like the youth contracts in Denmark or the Scottish hearings

148 Ibid at 285, 289.

149 See generally Roberts et al, supra note 3 .

150 See e.g. the election platforms for the then-ruling Conservative Party of Canada from the last two federal elections: Conservative Party of Canada, "Protect our Economy: Our Conservative Plan to Protect the Economy" (2015), online: $<$ www.conservative.ca/media/plan/conservative-platform-en.pdf> (deploring that "[f]or too long, Canada's system of justice had its priorities backwards: it focused on the so-called 'rights' and concerns of criminals, while victims and their families were left on the outside looking in" at 103); Conservative Party of Canada, "Here for Canada: Stephen Harper's Low-Tax Plan for Jobs and Economic Growth" (2011), online: <www.scribd.com/doc/52594069/Conservative-Party-ofCanada-2011-Election-Platform> (stressing the need to "help Canadians feel safe in their homes and in their communities" at 46).

151 UN Committee on the Rights of the Child, Concluding Observations: Canada, 5 October 2012, CRC/C/CAN/CO/3-4 at para 34 [UNCRC, Canada]. 
committee's advisory role for serious offenders processed before the courts, responses to punitive public sentiment should be embedded within the wider rehabilitative framework so as to avoid subsuming BICinspired approaches entirely.

Naturally, the competing considerations evidenced in the Canadian juvenile justice model's history cannot be displaced altogether. In order for the BIC principle to gain traction, the public must perceive it as compatible with other concerns. Children's best interests should be reconciled with dominant considerations, especially societal protection, and promoted as part and parcel of advancing public safety.

For instance, Freeman adopts a utilitarian argument in contending that "giving greater weight to children's best interests maximizes the welfare of society as a whole." $152 \mathrm{He}$ relies partly on the emphasis that countries recovering from a period of rightlessness afford children's interests to illustrate that prioritizing youth is a means of developing the future. ${ }^{153}$ Freeman also points to the work of Barton and Douglas. In their legal assessment of parenthood, the authors underline that "socialization of children is crucial for the continuity of order in society." 154 The state's longstanding commitment to the formal education of children stands as a testament to this fact. ${ }^{155}$

Conversely, subjecting children to the rigours of the criminal law may undermine Parliament's commitment to societal protection. Newell argues that criminalizing youth causes ongoing harm to children and society as well. Indeed, criminalization breeds progressively more violent offending that may manifest itself into adulthood. ${ }^{156}$ In promoting the BIC principle, the Committee on the Rights of the Child reminds stakeholders that abiding by rehabilitative and restorative justice objectives is compatible with maintaining effective public safety. ${ }^{157}$

\section{Reconsidering Proportionality}

While confronting penal populism is a necessary condition for prioritizing children's best interests, it is not sufficient in and of itself. Proponents of the BIC principle must also redefine a concept that is deeply engrained in Canadian criminal law, that of proportionality. Proportionality, as it is understood in criminal justice, denotes a response that reflects an offence's seriousness and the offender's degree of responsibility. The concept is generally applied in the area of sentencing or in deciding whether to pursue extrajudicial means of resolution.

Broadly speaking, proportionality is geared toward protecting the interests of the accused and those of society. On the one hand, proportionality may act as a brake on sentencing. Less serious crimes result in less severe sanctions. On the other hand, proportionality may function as a lower limit on punishment by setting the minimum level of severity needed to respond to an offence's seriousness. In both cases, it establishes the appropriate degree of intervention required to hold an offender accountable. ${ }^{158}$

52 Supra note 5 at 41.

153 Ibid.

154 Chris Barton \& Gillian Douglas, Law and Parenthood (London, UK: Butterworths, 1995) at 423.

155 Ibid.

156 See Newell, supra note 19 at 137.

157 See UNCRC, General Comment No 10, supra note 13 at para $4 \mathrm{~b}$.

158 See Richard Barnhorst, "The Youth Criminal Justice Act: New Directions and Implementation Issues" (2004) 46 Can J Corr 231 at 234. 
The YCJA officially introduced proportionality to the Canadian youth justice framework. Although it was one of many factors judges considered when crafting a sentence under the YOA, proportionality was not a requirement. ${ }^{159}$ With the coming into force of the YCJA, proportionality assumed a prominent position in the new legislation's declaration of principles. ${ }^{160}$ According to Bala, proportionality's inclusion in the Act's declaration signalled that incarceration could not be justified on the grounds of promoting rehabilitation or child welfare. ${ }^{161}$ One of its core objectives was to prevent the overuse of coercive state measures as a response to minor offending.

Parliament intended for proportionality to play a preeminent role in sentencing, as evidenced by its position in the YCJA's list of sentencing principles. ${ }^{162}$ Section 38(2)(c) of the Act states that a sentence must be proportionate to the offence's seriousness and the young person's degree of responsibility. Other principles, including rehabilitation and the use of the least restrictive sentence possible, are introduced as "subject to paragraph (c)." 163 As Barnhorst concludes, "[p]roportionality is the primary or dominant requirement that addresses severity, and rehabilitation is a secondary requirement that addresses the types of measures to be used within a proportionate sentence." 164

If the Canadian youth justice framework is to prioritize the BIC principle by drawing on the international practices outlined above, it must rethink proportionality's centrality in sentencing. At the moment, proportionality, by virtue of its primacy among sentencing principles, sets the sentence's requisite severity. This in turn affects the availability of rehabilitative and less restrictive sentences, with extensive rehabilitation being unavailable for minor crimes and serious offences requiring stiffer penalties.

Depending on the international practices Parliament adopts, it may move to exclude further minor offences from the youth justice system (e.g. through mandatory diversion, decriminalization of petty crimes, etc.) such that the courts will only process comparatively serious delinquency. With most offences before the courts being of a serious nature, proportionality would no longer serve to prevent minor offenders from receiving disproportionately long sentences. Instead, it would almost invariably act strictly as a lower limit on sentencing. Proportionality would set a range of severe sanctions from which the most rehabilitative option could then be chosen. Explained differently, the starting point for almost all matters that proceed through the courts would be a harsh sentencing position, with consideration of the child's needs to follow.

A youth justice framework where consideration of children's interests is secondary to the severity of punishment is not compatible with prioritizing the BIC principle. After all, as Trépanier notes, proportionality's function as a lower limit "has nothing to do with education or rehabilitation, but rather is an expression of such goals as retribution, deterrence, or denunciation that are more akin to adult than youth justice." 165

Rebalancing proportionality's role at the sentencing stage entails legislative amendments. Specifically, it would require removing the words "subject to paragraph (c)" from s.38(2)(e) such that the sentencing

159 See Jessica E Pulis \& Jane B Sprott, "Probation Sentences and Proportionality under the Young Offenders Act and the Youth Criminal Justice Act" (2005) 47 Can J Corr 709 at 710.

160 See Youth Criminal Justice Act, supra note 1, s 3(1)(c).

161 See Bala, "Development," supra note 30 at 50.

162 See Youth Criminal Justice Act, supra note 1, s 38(2).

163 Ibid, s 38(e).

164 Barnhorst, supra note 158 at 244.

165 Trépanier, supra note 43 at 288. 
principles listed in that section would be on equal footing. Proportionality would not be removed from the equation. Rather, judges would be called upon to balance proportionality with rehabilitative concerns.

Scaling back proportionality's centrality without eliminating it from the list of sentencing principles is compatible with prioritizing children's best interests. To the extent that a proportionate sentence is one that holds a youth accountable, it reflects the BIC principle's developmental underpinnings. Instilling in youth some level of accountability for the commission of serious offences is a component of fostering their holistic development. Furthermore, it will be recalled that the BIC principle does not displace other considerations altogether. The BIC principle can be prioritized without fully subsuming traditional criminal justice concerns so long as children's interests do not become secondary to those competing considerations.

Similarly, removing proportionality's dominance over other sentencing principles would not signal a return to the onerous compulsory interventions that existed under previous youth justice legislation. First, children are now protected by a number of general rights that were not recognized or precisely defined when the JDA was in force. The development of children's legal rights facilitates the promotion of children's interests. While the scope of these protections is too broad to dissect here, it may suffice for the purpose of this analysis to underscore modern conceptions of the rights to due process and against cruel and unusual punishment. ${ }^{166}$

Second, and perhaps more importantly, youth would continue to enjoy the protection of the YCJA's provisions. Generally speaking, sentences would be limited by the need to be less punitive than those meted out to adults ${ }^{167}$ and to reflect the young person's diminished mental blameworthiness. ${ }^{168}$ They would still have to be the least restrictive dispositions possible ${ }^{169}$ and the use of custody as a substitute for appropriate social measures, mental health or child protection would remain statutorily prohibited. ${ }^{170}$ Finally, unlike under the YOA, proportionality would remain a listed principle which judges would need to apply when passing a sentence.

After the words "subject to paragraph (c)" are removed from s.38(2)(e), sentencing would continue to be a highly individualized process. Judges would apply proportionality as part of that process. However, when an otherwise proportionate sentence is decidedly incompatible with the BIC principle, the sentencing judge would not be constrained by proportionality. Whether this amendment is necessary would depend on the methods Parliament chooses to prioritize children's best interests. If that choice involves removing most minor offences from the courts, the centrality of proportionality, which would then almost invariably act as a punitive threshold, would need to be reconsidered.

\section{CONCLUSION}

Penal populism's continued political appeal at home and abroad can easily eclipse policy objectives premised on development and rehabilitation. This is especially so for concerns tied to the wellbeing of

166 See Canadian Charter of Rights and Freedoms, Part I of the Constitution Act, 1982, being Schedule B to the Canada Act 1982 (UK), 1982, c 11, ss 7, 12.

167 See Youth Criminal Justice Act, supra note 1, s 38(2).

168 Ibid, s 3(b).

169 Ibid, s 38(2)(e)(i).

170 Ibid, s 39(5). 
children, whose main beneficiaries are dependent on others to advocate for their interests. Notwithstanding its obligations under Article 3 of the UNCRC, Canada has thus far avoided prioritizing the BIC principle over traditional criminal justice objectives. Disregard for this international commitment has resulted in the preservation of a court-based system that is overly reliant on formal processing and incarceration compared to other developed countries.

Western jurisdictions that have adapted their conventional court-based models exemplify short-, medium- and long-term means of promoting the BIC principle. In the immediate future, Parliament may promote children's interests by removing less serious cases from the formal youth justice system (e.g. by increasing the age of criminal responsibility, removing sanctions for petty offences, and instituting mandatory diversion). Minor delinquency could then be addressed through less formal rehabilitative rather than punitive measures. Moving to the medium-term, policymakers may wish to ensure that those who adjudicate youth cases, be they judges or other professionals, have a background and an interest in responding to children's needs. A more involved role for welfare agencies and their staff would facilitate this objective. Looking further down the road, policymakers should consider models that respond to children's delinquent behaviour outside the criminal justice apparatus by addressing their needs instead of their actions. Breaking from a youth justice system that mirrors the practices of adult prosecutions would be an ambitious reform but, as the hearings system Scotland has employed since the 1970s shows, an attainable one nonetheless.

Whatever methods Canada chooses to revive concern for the BIC principle, those policies would operate in a different legal environment than they did under past youth justice legislation. The recognition of children's rights has progressed such that it prevents the indefinite coercive treatment that was possible under the JDA. Youth can now invoke protections under the Charter and the YCJA to guard against intrusive state measures aimed at responding to minor offending. Developments in the area of children's rights allow for an implementation of children's interests that was not possible when it was attempted in the early $20^{\text {th }}$ century.

Should Canada take the first steps toward prioritizing children's best interests by removing less serious offences from the youth justice system, it will need to rethink proportionality's centrality at the sentencing stage. With only comparatively serious offences being heard before the courts, there is a genuine risk that the severity of punishment dictated by proportionality will unduly restrain the child-friendly disposal of cases. Other sentencing principles, including rehabilitation, must be weighed equally alongside proportionality to ensure that children's interests are not secondary to punishment.

The Canadian youth justice system as a whole stands to gain from foregrounding children's best interests. At the moment, however, concern for public safety and accountability overshadows the contributions a renewed focus on children's best interests could make to the field of criminal law. There is limited awareness that prioritizing the BIC principle would enable the country to faithfully fulfill its international commitments, foster societal development and critically assess the effectiveness of traditional crime-suppressing techniques. Advocates of the BIC principle must therefore promote children's interests not as a standalone concept, but as one that is inherent to advancing public safety and shaping future generations. 